\title{
Topography of the Moho Undulation in Cameroon from Gravity Data: Preliminary Insights into the Origin, the Age and the Structure of the Crust and the Upper Mantle across Cameroon and Adjacent Areas
}

\author{
Albert Eyike $^{1 *}$, Françoise Enyegue A. Nyam², Charles Antoine Basseka ${ }^{3}$ \\ ${ }^{1}$ Department of Physics, Faculty of Science, University of Douala, Douala, Cameroon \\ ${ }^{2}$ Department of Physics, Faculty of Science, University of Yaoundé I, Yaoundé, Cameroon \\ ${ }^{3}$ Department of Earth Science, Faculty of Science, University of Douala, Douala, Cameroon \\ Email: *aeyike@gmail.com
}

How to cite this paper: Eyike, A., Enyegue A. Nyam, F. and Basseka, C.A. (2018) Topography of the Moho Undulation in Cameroon from Gravity Data: Preliminary Insights into the Origin, the Age and the Structure of the Crust and the Upper Mantle across Cameroon and Adjacent Areas. Open Journal of Geology, 8, 65-85. https://doi.org/10.4236/ojg.2018.81005

Received: November 28, 2017

Accepted: January 27, 2018

Published: January 30, 2018

Copyright $\odot 2018$ by authors and Scientific Research Publishing Inc. This work is licensed under the Creative Commons Attribution-NonCommercial International License (CC BY-NC 4.0). http://creativecommons.org/licenses/by-nc/4.0/ (c) (i) \&) Open Access

\begin{abstract}
In this paper, the complete Bouguer anomaly data from Cameroon and part of the neighboring countries has been examined to compute the topography of the Moho undulations. This work is based on an improved filtering technique and an appropriate density contrast between the crust and the upper mantle. Comparison with seismic data shows that our Moho map defines better the continuity and morphology of the crust-mantle interface than the scattered seismic data in Cameroon. The present relief map, although may not give real depths at some areas provides a better surface correlation with the surface geology better than seismic techniques. Comparison between the Moho undulations and the topography maps reveals that the crust in Cameroon seems to not be in isostatic equilibrium. The Moho in the Central African Shear Zone (CASZ) must be linked with different dextral movements during the opening of the south Atlantic in the Cretaceous time. In the Chad basin, the Moho is associated to the opening of the central and south Atlantic $130 \mathrm{Ma}$. In the case of the Congo basin, the Moho undulations are related to the post rift subsidence. The correlation between the Moho undulations map with the surface geology indicates that the actual morphology of the crust mantle interface in Cameroon can be related to the build-up of the West and Central African rift system dating back to the Early Cretaceous to Palaeogene, where the presence of intraplate tensional stresses reactivated previous shear zones of lithospheric weakness during the break up of Gondwana.
\end{abstract}




\section{Keywords}

Crustal Instabilities, Gravity Anomaly, Moho Undulations, Cameroon

\section{Introduction}

The crustal structure knowledge is vital in geophysics, because it provides insights into the geohistory, tectonic environment and geohazard limitation ([1] [2] [3]). There is little knowledge about the crust in Cameroon in comparison to other countries in East Africa. The only published crustal thickness map of Cameroon and surrounding areas was prepared by [4]. However, this map is produced with a processing technique which averages the Moho so much that it is hard to correlate the Moho undulations with the surface geology. Further, this map is based on a very uneven distribution of data and the calculated depths are impossible in some places as they show important gaps with the deep seismic refraction data. Recently, [5] presented the structure of the crust in Cameroon using the joint inversion of Rayleigh wave group velocities and receiver functions. However, this study mainly focuses on the CVL in the expense of other places where the crust structure is not well constrained.

Estimates of crustal structure and Moho depth in particular, place preliminary constraints on geochemical and tectonic processes that have led to crustal formation and evolution. Thus, improved estimates of crustal structure in Cameroon are needed.

In this study, we investigate crustal structure of Cameroon and adjacent regions in using a set of 2.5D gravity models of this area. These gravity models are constrained using available seismic, geological and petrophysical data interpretation.

By using this approach, it is possible to compute the entire map of the Moho undulation over Cameroon. The aim is to obtain preliminary insights into the origin, the age and the structure of the crust and the upper mantle across Cameroon and adjacent areas.

\section{Geology and Tectonic Background of Cameroon}

The comprehensive background of the geology and tectonic setting of the study area (Figure 1(a)) is summarized in [4] [5] [6] [7]. The geology mainly consists of distinct units covering from the Archean to the Cenozoic. The Precambrian basement of Cameroon is covered by Cretaceous to Cenozoic sedimentary formations. Most of these sediments rocks are found the Chad basin, including the Benue trough, the Garoua and the northern Chad basins, north of the area of study. Stratigraphic studies [8] showed that basement main rocks types are granite, charnockite and gneiss and they may be split in two units: 1) the Central African Shear Zone (CASZ) to the north, which belongs to the Oubanguides mobile belt and extends ENE-WSW to the Darfour region of Soudan by crossing 


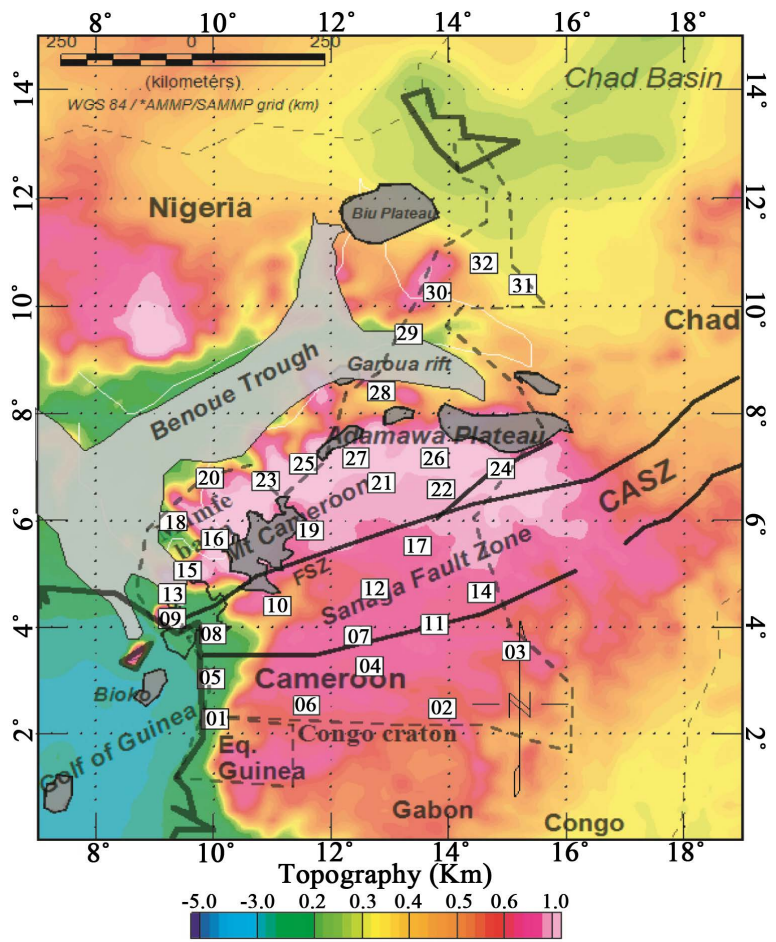

(a)

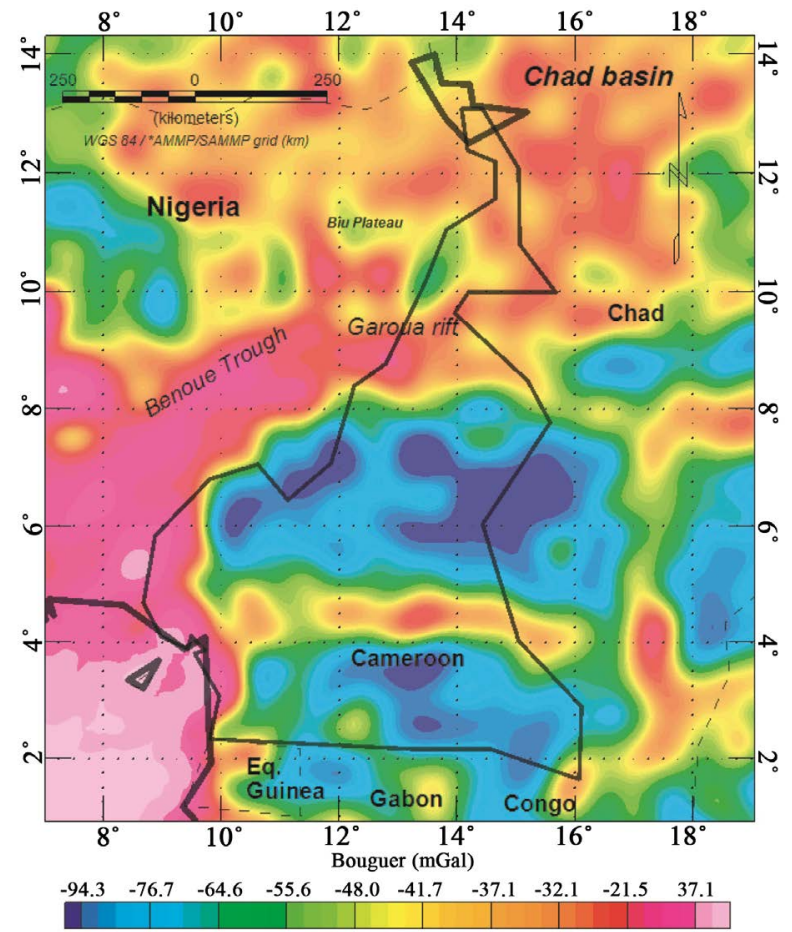

(b)

Figure 1. (a) Topographic map presenting the main geological features and major tectonic directions of Cameroon and approximate positions of some locations. Numbers in white squares refer to station codes used for comparison between Moho depths estimates from this study and estimates from seismic studies. FSZ, Foumban Shear Zone; CASZ, Central African Shear Zone; (b) the Bouguer anomaly map of Cameroon and adjoining regions. 
Cameroon and the Central African Republic (CAR), 2) the Archean Congo craton to the south, covers a large area and where it is known as the Ntem complex. The northern end of Congo craton is still controversial. [9] believe that there is a contact between the Pan African rocks and the Ntem complex along this boundary where they two form together an intracrustal discontinuity.

North of the Central African Shear Zone (CASZ) is the Cameroon Volcanic Line (CVL) a long chain Cenozoic feature which trends southwest to northeast and long of about $1700 \mathrm{~km}$ (Figure 1(a)). The absence of sufficient age progression and the occurrence of sporadic magma rise along the CVL volcanic centers have favored different possible models for the origin of the CVL including and well summarized in [10]. Ring complexes, with diameter ranging from $1-10 \mathrm{~km}$ are usually associated with the CVL. [11] [12] have reported the presence of more than 60 of these plutonic complexes in Cameroon where they are also known as "Granites Ultimes". These complexes comprise different rock types including granites and syenites. Mt Cameroon, southernmost of the CVL (Figure 1(a)) is the largest volcano of the continental sector of the CVL with a high of about 4100 meters, and a recurrent deep seismicity [11] [13] [14] [15]. In central Cameroon, there is the domal uplift of the Adamawa Plateau. It is the northeastern end of the CVL which uplifted in the Tertiary up to $1 \mathrm{~km}$ compared to the surrounding area [16]. Its volcanic activity has arise from Neogene to Recent times and mostly composed of phonolites, trachytes and alkali basalt [17].

\section{Gravity Data and Processing Techniques}

\subsection{Data}

The gravity dataset is extracted from the World Gravity Map (WGM) and made available by the Bureau Gravimétrique International (BGI). This gravity anomaly map is computed in spherical geometry, and takes into account a realistic Earth model. It results from the Earth gravity models (EGM2008, DTU10) and contains high resolution terrain corrections including contribution of most surface masses (atmosphere, oceans, land, inland seas, ice caps ice shelves and lakes). Such gravity anomaly $\left(2^{\prime} \times 2^{\prime}\right.$ resolution) which enhances the density heterogeneities in the Earth's interior (crust, mantle...) helps in many applications including geophysics, structural geology, geodesy (shape of the Earth, geoid), and exploration of natural resources (oil or mining prospecting) [18] (Bonvalot et al., 2012). Accurate computations at global scale have been performed using theoretical developments spherical harmonic [19].

The resulting Bouguer anomaly map is shown on Figure 1(b).

\subsection{Filtering}

The purpose of the present paper is the construction of the morphology pattern of the crustal-mantle interface. It is therefore necessary to remove short wavelength signals due to intracrustal sources and long wavelength signals caused by 
asthenospheric sources.

For this purpose, we analyze the anomalies using bidimensional filters, as described in [20] [21] [22] [23]. In order to obtain the suitable results, it was useful to evaluate based on geological criteria, a series of filtered fields, derived from a number of different cut-off wavelengths. Similar to [20] we compute a set of filtered maps, adopting cut-off wavelengths $(\lambda)$ varying from 200 to 700 $\mathrm{km}$.

In Figure 2(a), the filtered map of wavelength above $200 \mathrm{~km}$, it is possible that this map still reflects some local perturbations due to shallower structures like the series of small local gravity anomalies in the Central and Northern Cameroon, whereas the gravity signal map of wavelength above $300 \mathrm{~km}$ (Figure 2(b)) possibly only consist of the effects of the deeper structures such as, the Moho or the Lithosphere-Asthenosphere Boundary (LAB). The result of analogous computing process to isolate wavelengths above $300 \mathrm{~km}$ is presented in Figure 2(c) and Figure 2(d). Following different tests using various low-pass filters and where the gravity field variations were considered, it appeared suitable to suppose that the gravity field of wavelength above $300 \mathrm{~km}$ originate from lower crust and to the LAB sources, whereas the gravity field for wavelength above 700 $\mathrm{km}$ is possibly only due to the LAB. In the case of the bandpass filtering of $300<$ $\lambda<700 \mathrm{~km}$ (Figure 3), the derived field is essentially or completely due to the lower crust-mantle interface (Moho).

\subsection{Modeling}

To achieve a quantitative interpretation of the crust-mantle interface geometry of Cameroon, 16 profiles oriented west-east and 12 profiles oriented north-south were selected from the bandpass filtered map (Figure 3) with a regular spacing of around $100 \mathrm{~km}$. A $2.5 \mathrm{D}$ interpretation makes sense when profiles are perpendicular (or so) to the studied structures. In Figure 3, most of the structures are aligned roughly E-W, and therefore, horizontal profiles may seem not representative. However, they are critical for a better gridding of the Moho undulations.

Modelling of the whole lithosphere is difficult in the West and Central African Rift System (WCARS) due to the lack of constraining seismic data. For the present study, we take advantage of data from the newly Cameroon Broadband Seismic Experiment [5] [6] [7]. Crust layer densities were estimated from the [24] P-wave velocity-density empirical relationship. Crust layer velocities used and estimated densities for the layers are provided in Table 1.

The density value used for the crust is the average density value for the deeper rocks. We adopted a density contrast of $400 \mathrm{~kg} / \mathrm{m}^{3}$ between the mantle and the crust. By using the cut-off wavelength of $300<\lambda<700 \mathrm{~km}$ the field due to near surface crustal sources are considered has been removed. The interpretation was performed by a two layer model, using GMSYS 2.5 D modeling programs. The results of the modelled twenty eight profiles are shown on Figure 4. 


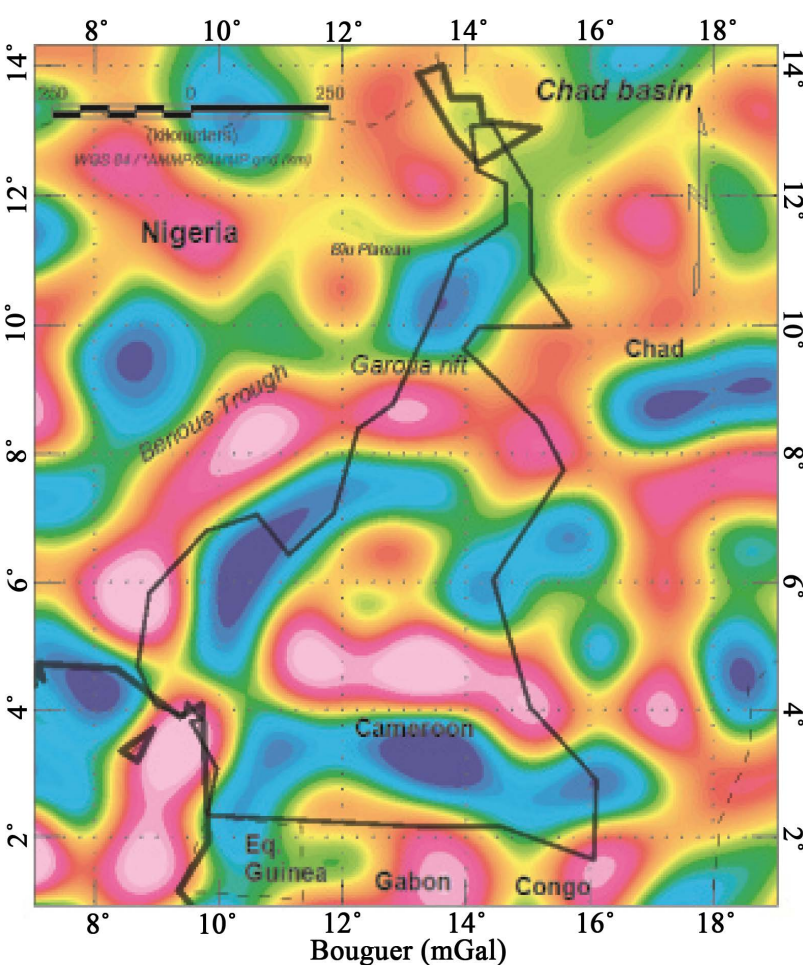

$\begin{array}{llllllllllll}-23.5 & -14.3 & -8.8 & -5.0 & -3.4 & -1.2 & 0.9 & 3.1 & 5.6 & 8.4 & 11.6 & 18.7\end{array}$

(a)

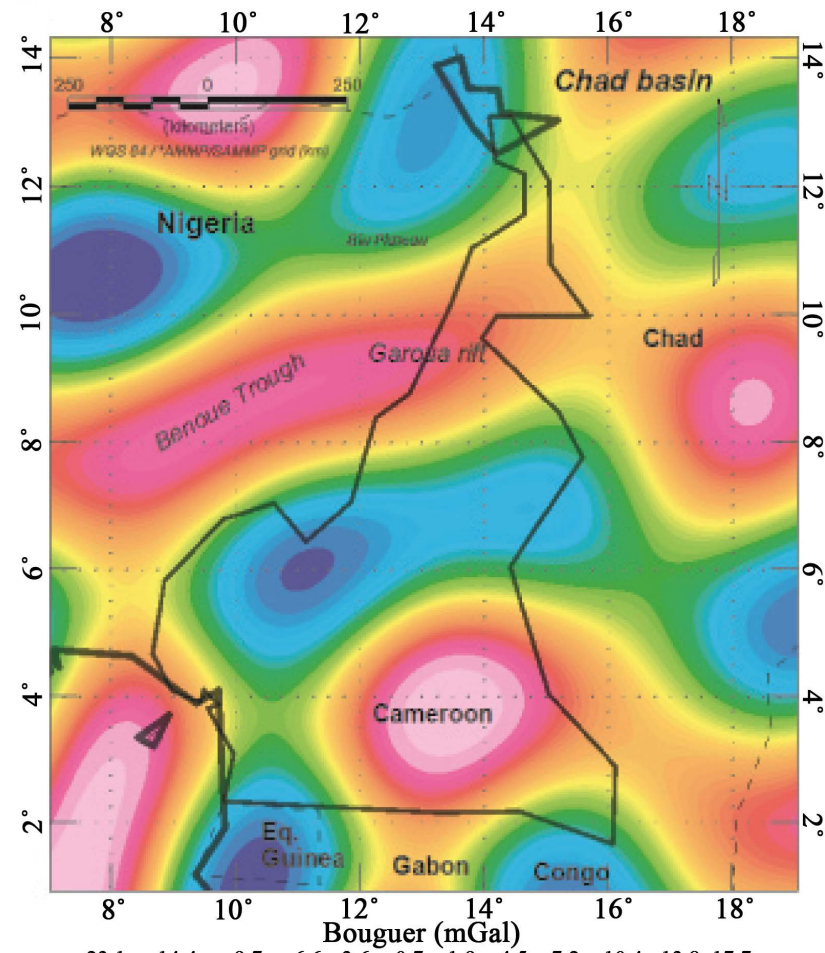

$\begin{array}{lllllllllllll}-23.1 & -14.4 & -9.7 & -6.6 & -3.6 & -0.7 & 1.9 & 4.5 & 7.2 & 10.4 & 13.8 & 17.7\end{array}$

(c)

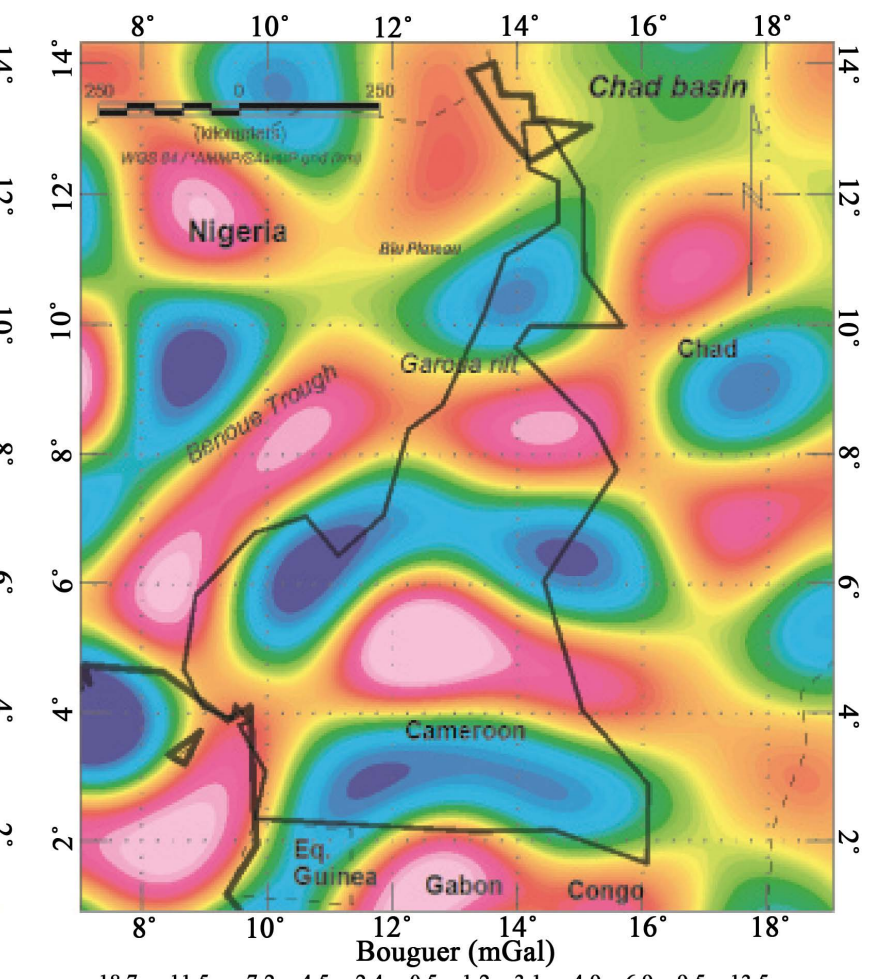

$\begin{array}{llllllllllll}-18.7 & -11.5 & -7.2 & -4.5 & -2.4 & -0.5 & 1.2 & 3.1 & 4.9 & 6.9 & 9.5 & 13.5\end{array}$

(b)

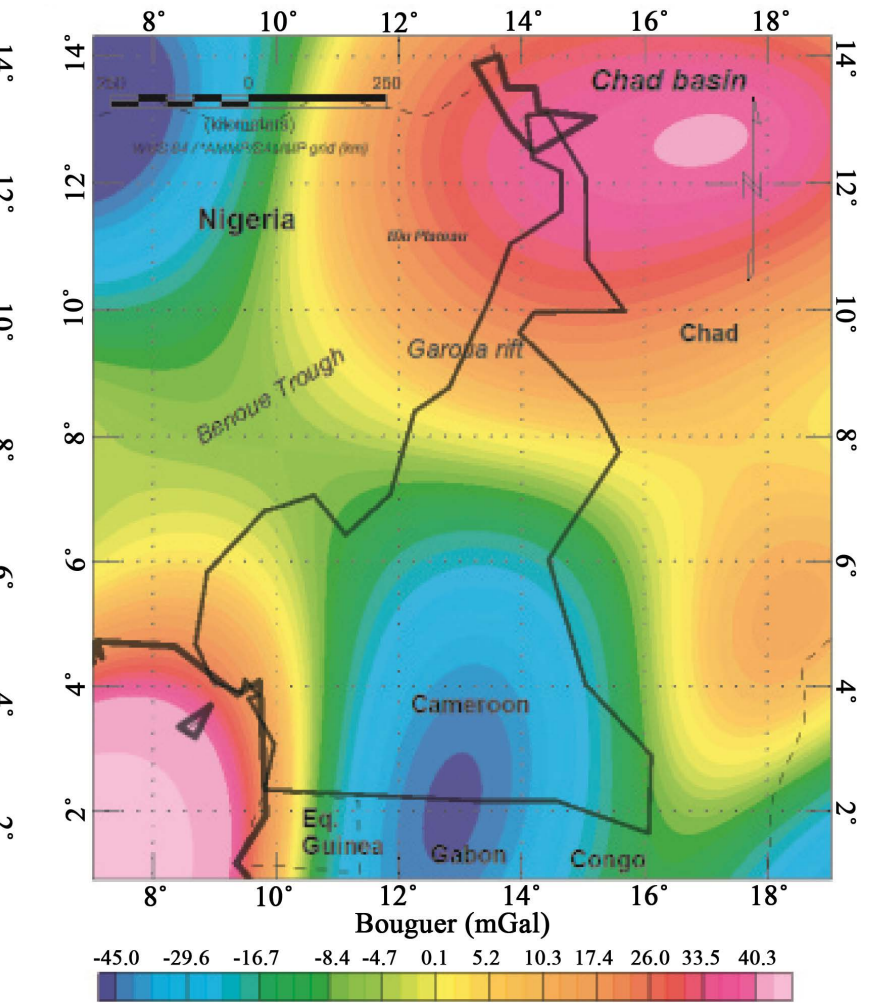

(d)

Figure 2. The filtered maps of Cameroon and adjacent regions. (a) The gravity decomposition of Cameroon, with wavelength above $200 \mathrm{~km}$; (b) wavelength above $300 \mathrm{~km}$; (c) wavelength above $400 \mathrm{~km}$; and (d) wavelength above $700 \mathrm{~km}$. 


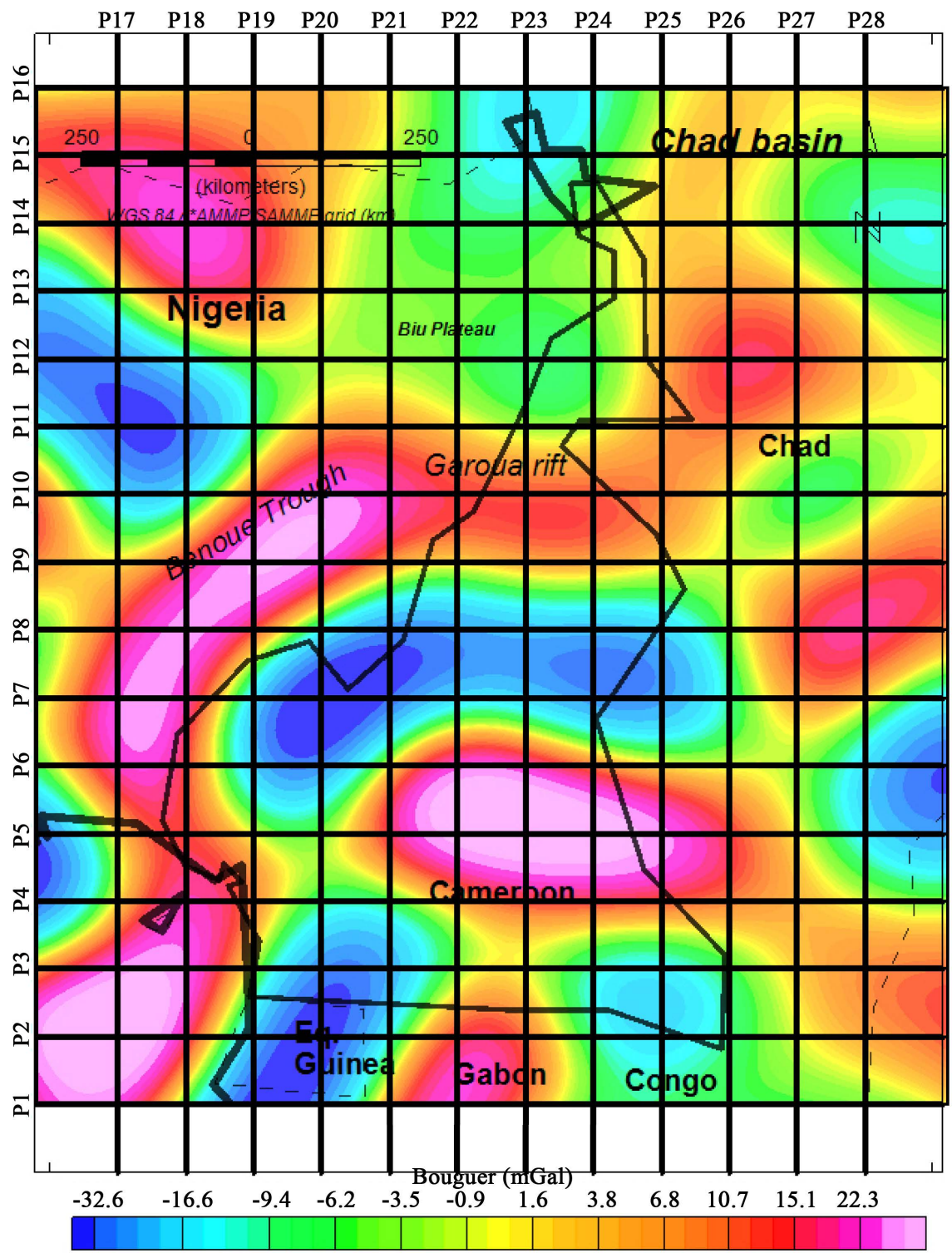

Figure 3. The filtered gravity anomaly of Cameroon and adjacent regions. The gravity part with wavelength between 300 and $700 \mathrm{~km}$ is supposed to have been removed as this is likely to originate from lower crust-mantle sources. The twenty height interpretative profiles are also shown.

Table 1. Density values used for the gravity modeling. Densities of crustal units are obtained by using the relationship between $P$-wave velocity and density [24].

\begin{tabular}{ccc}
\hline & $p$-wave velocity $(\mathrm{m} / \mathrm{s})$ Density $\left(\mathrm{kg} / \mathrm{m}^{3}\right)$ & \\
\hline $2000-4500$ & $2000-2490$ & Sediment cover \\
$5500-6000$ & $2650-2710$ & basement \\
$6000-6800$ & $2710-2860$ & Middle crust \\
$6800-7100$ & $2860-2960$ & Lower crust \\
8200 & 3300 & mantle
\end{tabular}



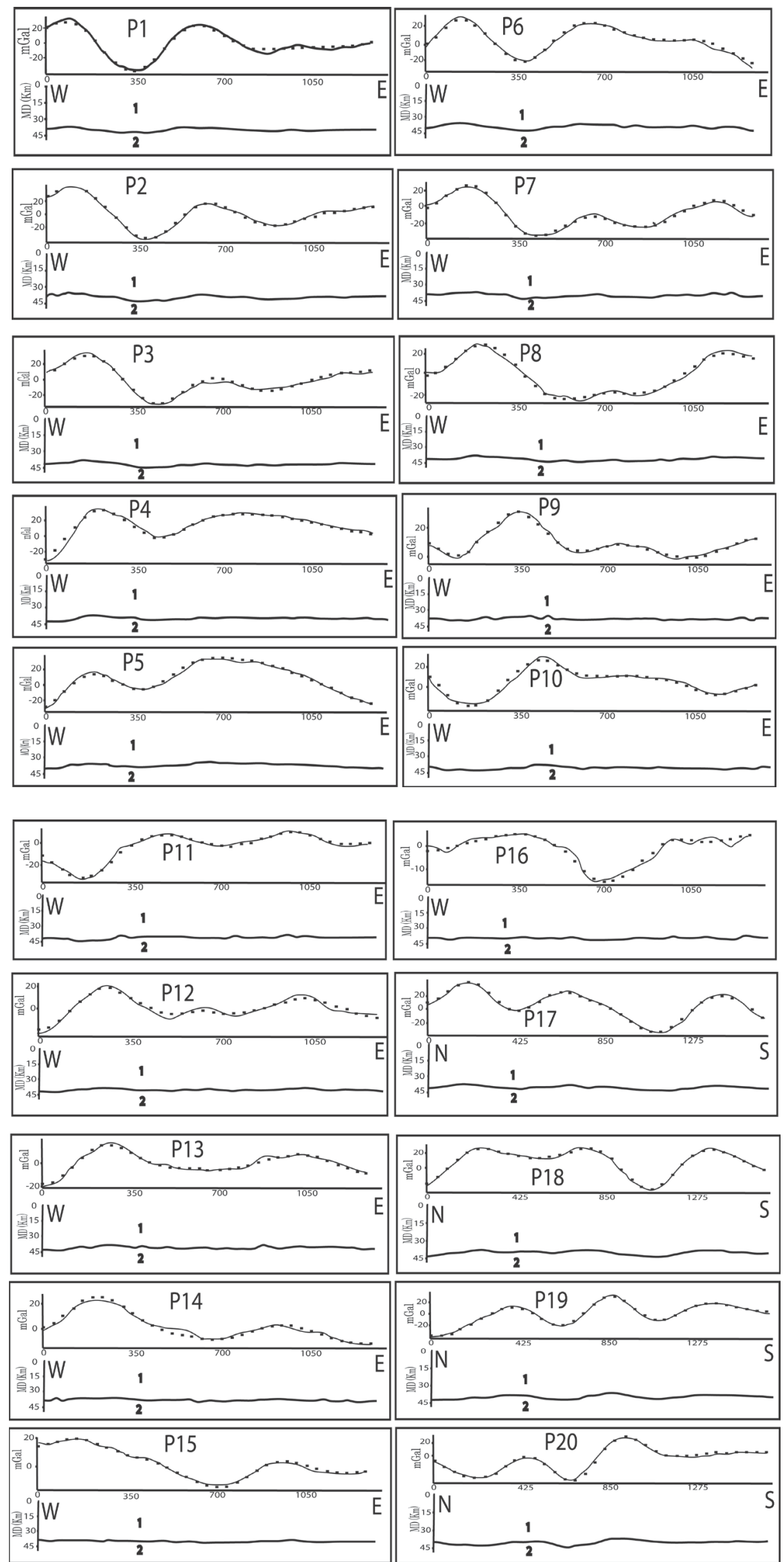

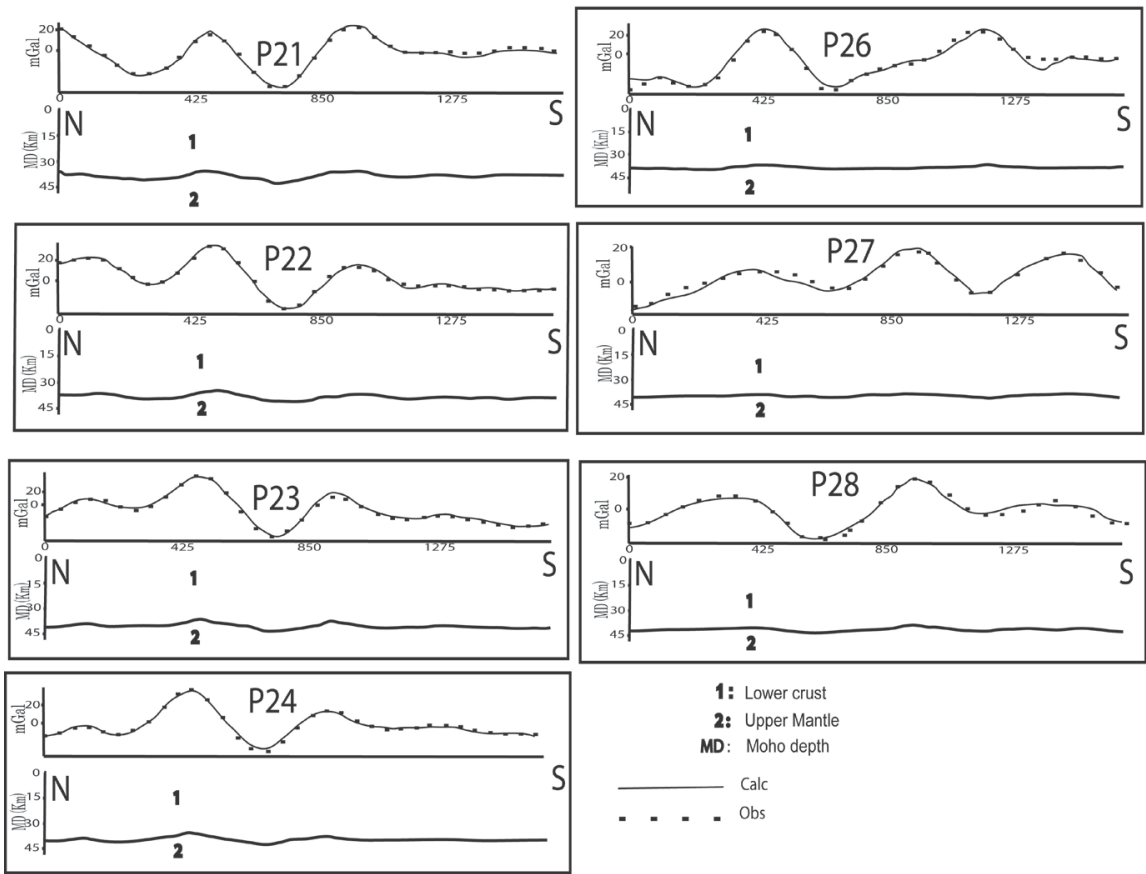

1: Lower crust

2: Upper Mantle

MD: Moho depth

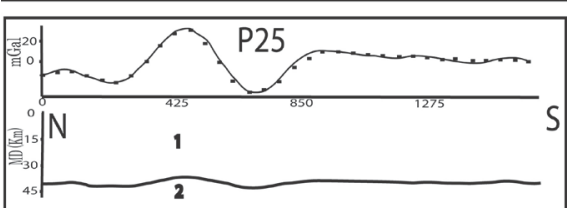

- Cak

$. \quad-$ Obs

Figure 4. The lower crust-upper mantle density structure along profiles selected from the filtered field map of Cameroon and adjacent regions. We used a density contrast of 400 $\mathrm{kg} / \mathrm{m}^{3}$ between the crust and the mantle. Profile distances are in kilometers.

\section{Results}

As the purpose of this work is to represent the regional geometrical trend of the Moho, the crustal depths derived from the 28 profiles were mapped using Geosoft contouring program. This map (Figure 5) is considered as reflecting the variations of the crust-mantle interface but not certainly its real depths. It can also be observed from Figure 5 the presence of high (red) and low (blue) Moho depths, and that the minimum and maximum amplitudes of these variations reach respectively 45 and $33 \mathrm{~km}$, with the highest difference of about $12 \mathrm{~km}$.

The present Moho depths are not automatically similar to the depths derived from seismic methods. These high and low depths are obtained with respect to the geoid, and do not absolutely correspond with zones of crustal thinning or thickening. Crustal thinning or thickening is determined when the Moho depths are obtained with respect to the topography.

The Moho topography (crustal thickness) was examined across Cameroon with respect to major tectonic terrains, as defined by [4] [5] and results were compared with previous crustal thickness estimates for similar terrains. Four domains can be clearly identified:

1) The Cameroon Volcanic Line domain (CVLd) is characterized by one elongated low ridge to its southern part in the oceanic sector. To the northern 


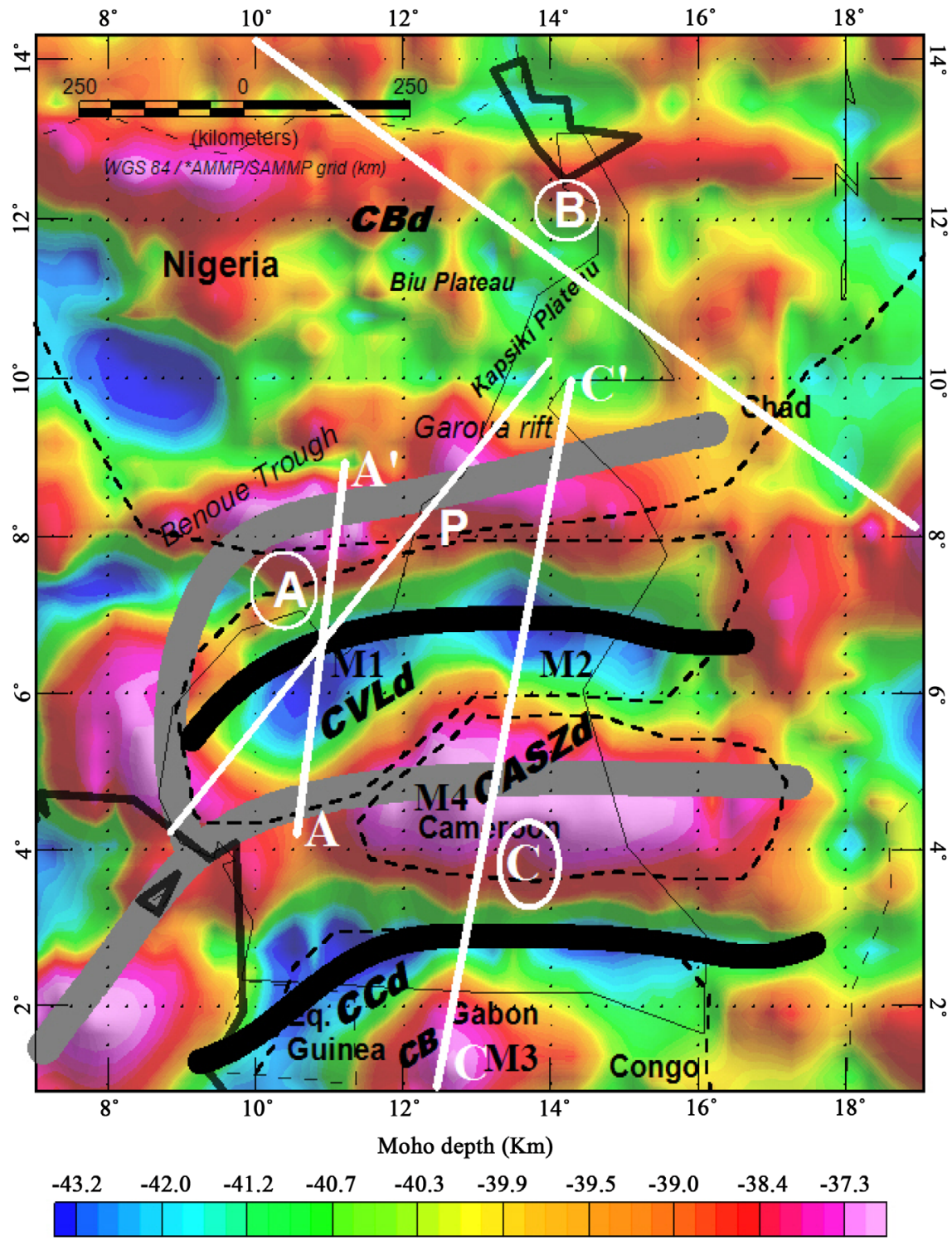

Figure 5. The Moho undulations in Cameroon and surrounding regions. Thick gray: Shallower Moho. Thick black: deeper Moho. Dashed lines: Different domains. Symbols are: $C B$ : The Congo basin; $C C d$ : The Congo Craton domain; $C B d$ : The Chad Basin domain; CASZd: The Central African Shear Zone domain; $C V L d$ : The Comeroon volcanic line domain. $\mathrm{M}_{1}-\mathrm{M}_{4}$ : Different Moho ridges. The position of sections $\mathrm{A}$ and $\mathrm{B}$ and $\mathrm{C}$ of Figure 7 is indicated.

part, there are two low ridges $\left(M_{1}, M_{2}\right)$ probably corresponding to the roots of the Adamawa Plateau and the Mont Cameroon uplifts areas. In this domain, the Moho depth varies from 32 to $43 \mathrm{~km}$ with the minimum depth towards the coast. These estimates of crustal thickness are almost similar to those found by [5] [10] in the same terrains.

2) The Central African Shear Zone domain (CASZd) is likely shows a single and well defined large high ridge (M4) slightly oriented ENE-WSW. Here the Moho depths obtained varies from 36 to $40 \mathrm{~km}$. There is no significant discre- 
pancy with the average values reported by [5].

3) The Congo craton domain (CCd) does not seem to represent a unique ridge. Moho depth over this craton is minimum (36 km) on its center, in the Congo basin and maximum $(45 \mathrm{~km})$ away from the center with a rapid thinning northward in the border with the Oubanguides fold belt. Our depths seem in accordance with [4] $(40 \mathrm{~km})$ but there is a significant discrepancy with the average values reported by [5] $(50 \mathrm{~km})$.

4) Chad basin domain (CBd) represents a large surface alternating highs and lows. The Moho depths are minimum on top of the Benue and the Garoua rifts and in the northern Biu Plateau. The mean depth is of about $33 \mathrm{~km}$ in this area. The Garoua rift shows an elongated high ridge slightly oriented east-west that abut the Adamawa plateau to the south and the Kapsiki plateau to the north.

In summary, our estimates of the Moho depths are in a relatively good agreement with previous estimates in the same terrains. Table 2 and Figure 6 show the comparison between Moho depths estimates from this study with previous seismic estimates [5] [25] [26]. It can be seen that the mean absolute difference is around $6 \mathrm{~km}$ between the gravity and the seismic estimates. Compared with the maximum depth of $48 \mathrm{~km}$, this difference may be considered as minor, even though the gap of $6 \mathrm{~km}$ may seem significant in some places. This discrepancy may be related to different factors: 1) our result assumes a constant density contrast throughout the area. The area being formed by suturing of different tectonic blocks, it cannot be excluded that lateral variations of density contrast are present and could have affected our Moho depths; 2) seismic studies (e.g. [5] [25] indicate that in some places there are two depths at which the shear wave increases, especially in St09 and St01 SW of Figure 1(a), where the velocity increases to $>4.3 \mathrm{~km} \cdot \mathrm{s}^{-1}$, at $25.5 \mathrm{~km}$ and at $40.5 \mathrm{~km}$, suggesting the presence of the Moho at shallower surface in this area. These considerations could not be solved in our simplified gravity model.

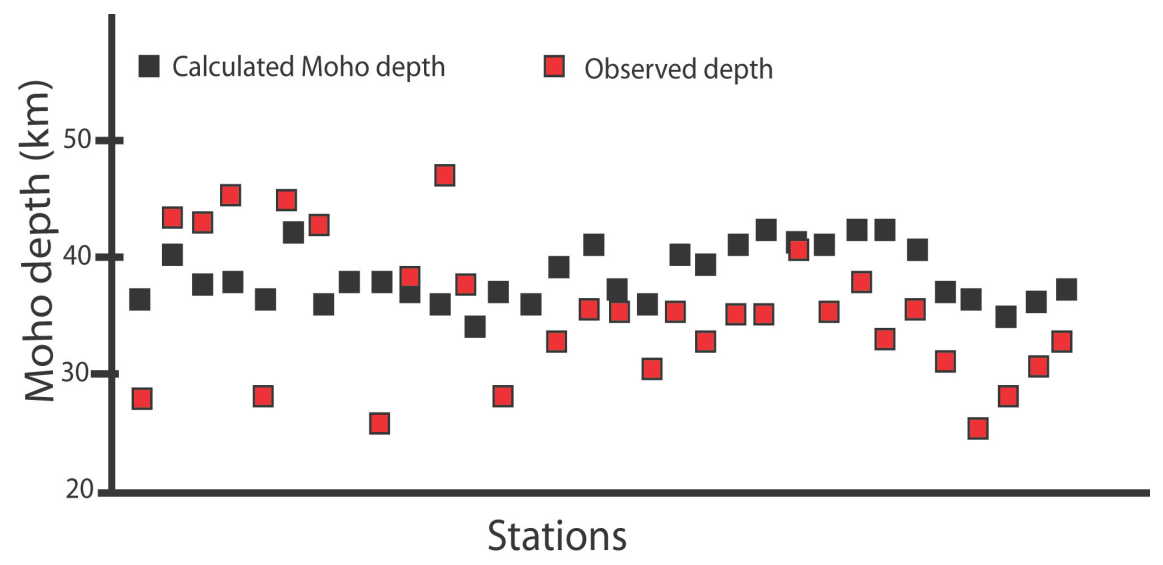

Figure 6. Scatterplot showing observed versus calculated Moho depths at different stations in Figure 1(a). Colored symbols: red refers to the observed Moho and black refers to modeled Moho. Note the relative close correlation between he observed versus calculated Moho depths. 
Table 2. Comparison of Moho depths estimates from this study with estimates from seismic studies from selected stations shown in Figure 1(a).

\begin{tabular}{|c|c|c|c|}
\hline Stations & $\begin{array}{l}\text { Modeled Moho depths } \\
\text { from gravity }(\mathrm{km})\end{array}$ & $\begin{array}{c}\text { Observed depths } \\
\text { from seismic data }(\mathrm{km})\end{array}$ & $\begin{array}{c}\text { Absolute Difference } \\
(\mathrm{km})\end{array}$ \\
\hline St01 & 38 & 28 & 10 \\
\hline St02 & 40 & 43 & 3 \\
\hline St03 & 38 & 43 & 5 \\
\hline St04 & 38 & 45.5 & 7.5 \\
\hline St05 & 36 & 28 & 8 \\
\hline St06 & 42 & 45.5 & 3.5 \\
\hline St07 & 36 & 43 & 7 \\
\hline St08 & 38 & - & \\
\hline St09 & 38 & 25.5 & 12.5 \\
\hline St10 & 37 & 38 & 1 \\
\hline St11 & 36 & 48 & 12 \\
\hline St12 & 34 & 38 & 4 \\
\hline St13 & 37 & 28 & 9 \\
\hline St14 & 36 & - & \\
\hline St15 & 39 & 33 & 6 \\
\hline St16 & 41 & 35.5 & 5.5 \\
\hline St17 & 37 & 35.5 & 1.5 \\
\hline St18 & 36 & 30.5 & 5.5 \\
\hline St19 & 40 & 35.5 & 4.5 \\
\hline St20 & 39 & 33 & 6 \\
\hline St21 & 41 & 35.5 & 5.5 \\
\hline St22 & 42 & 35.5 & 6.5 \\
\hline St23 & 41 & 40.5 & 0.5 \\
\hline St24 & 41 & 35.5 & 5.5 \\
\hline St25 & 42 & 38 & 4 \\
\hline St26 & 42 & 33 & 9 \\
\hline St27 & 41 & 35.5 & 5.5 \\
\hline St28 & 37 & 30.5 & 6.5 \\
\hline St29 & 36 & 25.5 & 10.5 \\
\hline St30 & 35 & 28 & 7 \\
\hline St31 & 36 & 30.5 & 5.5 \\
\hline St32 & 37 & 33 & 4 \\
\hline
\end{tabular}




\section{Discussion on the Origin and Age of the Moho Undulations}

Considering the non-uniqueness of the solutions resulting from the gravity data interpretation, it is essential to discuss whether the calculated long wavelengths gravity highs and lows originate from variations in crustal thicknesses and not by differences in the mantle density or to deep intracrustal bodies.

In Cameroon and Central Africa, mantle velocities variations are well known [6] [27]-[33]. However, the amplitudes of these variations (which are related to density variations), a few tens of kilometer are much smaller than those of the Moho undulations presented on the present study (a few hundreds of kilometer). This result is in agreement with previous results [20] [34] [35] who ensure that the range wavelengths of the crust-mantle interfaces usually of a few hundred kilometers, even though shorter wavelengths may exist in rifts or continental margins [36]. Additionally, seismic refraction studies [26] [31] suggest that most of the crust in Cameroon is devoid of low-velocity layer. Therefore, our gravity analysis could not be affected by a mid-crustal low-density body. Further, when seismic data are accessible, the correlation is usually remarkable between gravity and seismic Moho undulations. For example, comparison between the gravity ridges $M_{1}$ and the Garoua rift delineated beneath the CVL and the Moho depth resulting from the seismic studies [5] exhibit the similar nature of undulations although the gravity Moho is $6 \mathrm{~km}$ deeper than the seismic Moho (Figure 7). However, as stated above, this discrepancy does not exceed the mean absolute difference between the gravity and the seismic Moho. Two distinct approaches can be applied to assess the age and the origin of the Moho undulations [37] [38]. Firstly, the undulations of the Moho are compared with the topography to examine if these Moho trends are associated with an extensional or with a compressional episode. In secondly, the Moho undulations are examined, in planview, to check if they are related to dated geological structures.

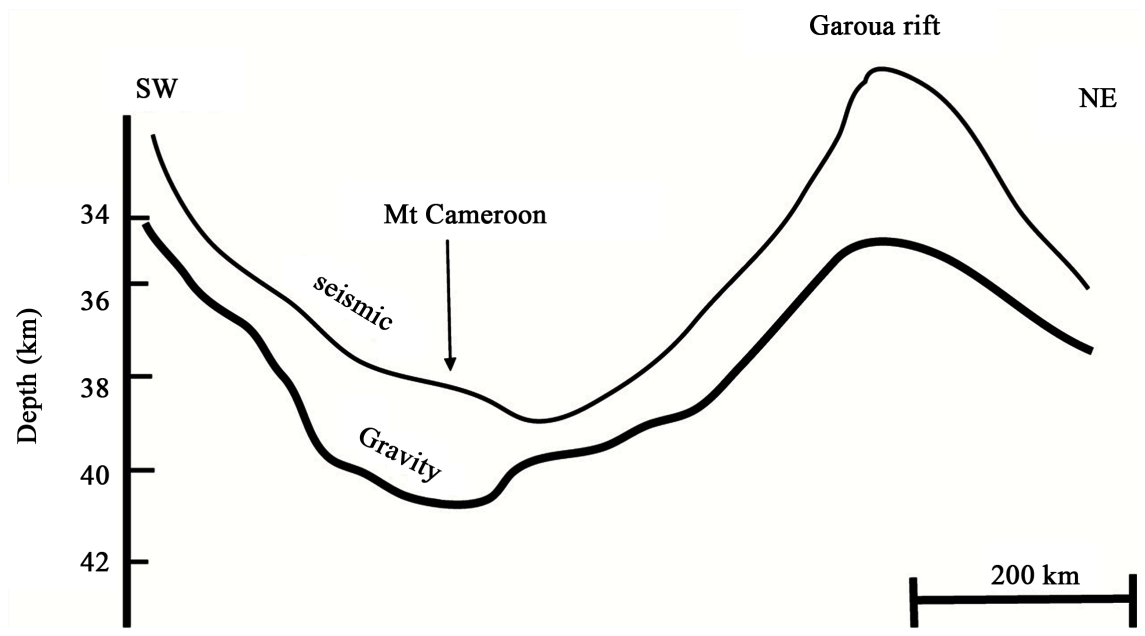

Figure 7. Comparison of Moho amplitudes from gravity and seismic data over the selected section $P$ of Figure 5. 


\subsection{Comparison between the Topography and the Moho Undulations}

The objective of this part is to examine if the Moho undulations stem from an extensional or a compressional phase.

When the topography and the Moho undulations are compared, various types of correlation can be identified. For different chosen sections (Figure 5), the correlation between the topography and the Moho undulations is displayed. It is worth to mention that this correlation is not determined by the location of the section, as changing the location of any section in a particular domain will lead to a similar result.

1) The deeper Moho depths overlay the topographic highs

This is recognized in the Cameroon Volcanic line domain; (Figure 8(a) and the northern end of section C) although the Moho depths and the topography are not imaged at the same range, there are marking variations of the crustal thickness in this domain.

According to [37], section A reminds structures achieved by compressional regime on an experimental crustal modeling process. We may therefore assume that the Moho undulations observed in the CVL domain (CVLd) evolved during an compressional episode.

2) The deepest Moho depths overlay the topographic lows. This is recognized in the Chad basin (Figure 8(b)). This section shows an obvious change in the crustal thickness. This type of undulation is certainly associated with an extensional process [37]. It can thus be assumed that the Moho undulations observed in the Chad basin domain can be linked with an extensional episode. This observation is in good agreement with [39] who previously mapped extensional phase in the Chad basin.

3 ) in the case of the particular undulations depicted in the Central African Shear Zone domain (CASZd) and the Congo Basin (CB) (Figure 8(c)), there is no clear correspondence between the surface topography and the Moho undulations wherever the position of the section. These structures are therefore neither linked with an extensional nor with a compressional event. An alternative solution, in the case of the CASZd, is that this feature could be linked from a deep-seated fault.

\subsection{Correlation between the Surface Geology and the Moho Undulations}

The objective of this analysis is to date the Moho undulations base on given geological criteria Table 3 compiles various relations that are observed between the recognized subsurface geological structures and the Moho undulations. From this comparison the following conclusions can be drawn:

The geological structures that overlap with the Moho undulations of the continental part of the Cameroon Volcanic Line domain $\left(\mathrm{M}_{1}\right.$ and $\left.\mathrm{M}_{2}\right)$ are in most cases linked with uplifts or basins of Tertiary age. We may suggest from these observations that there must have been a link between the Moho undulations 


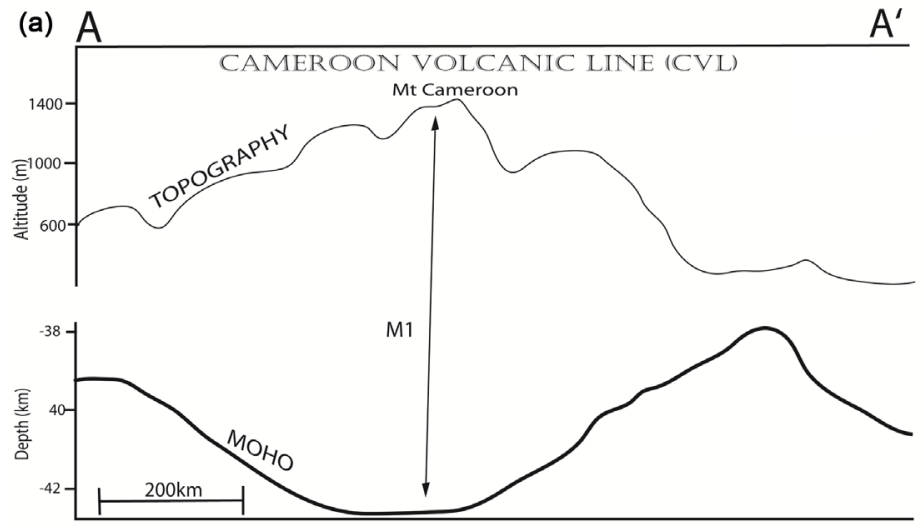

$A^{\prime}$
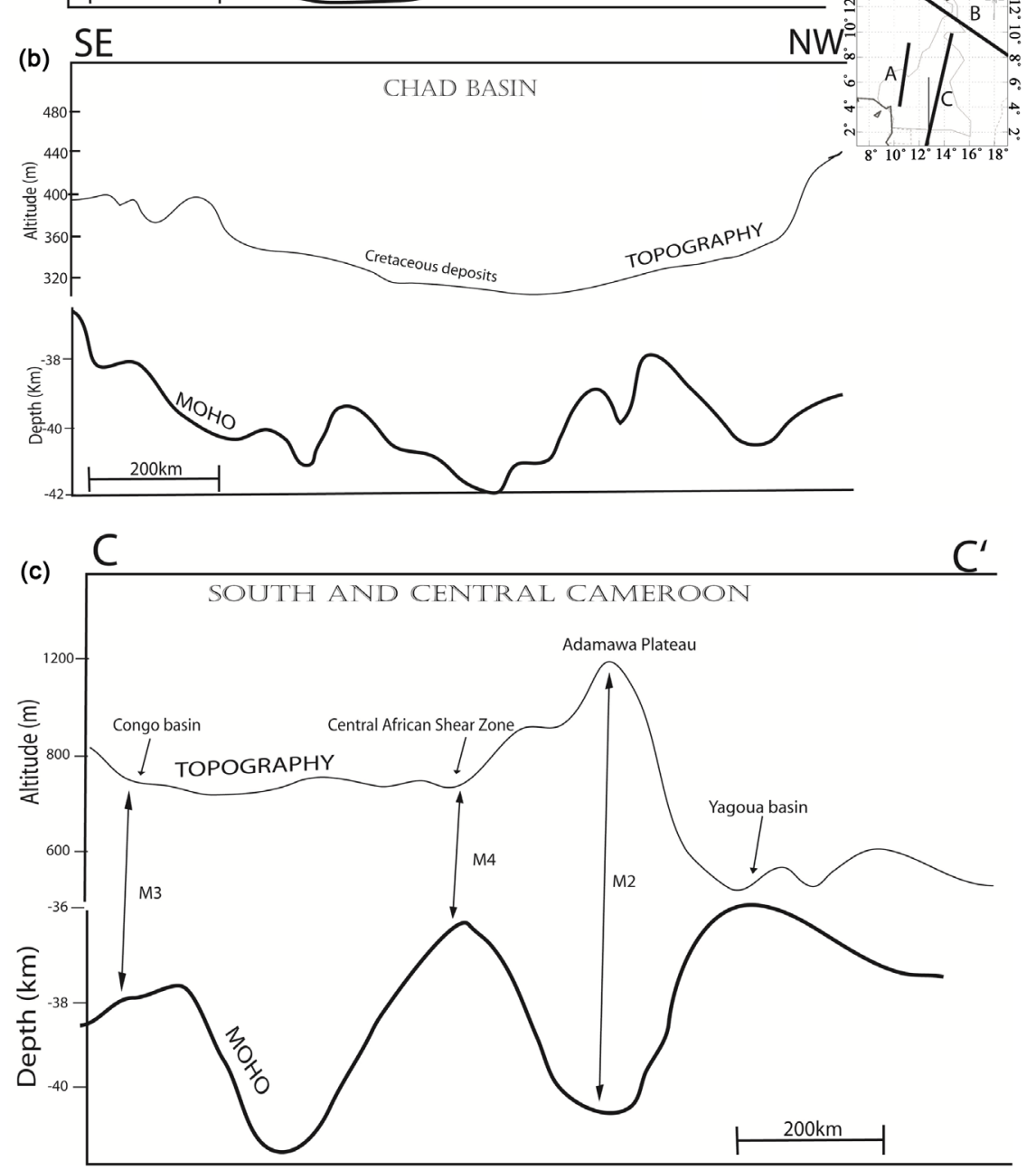

Figure 8. Selected sections showing the crustal instabilities recognized after comparison between the gravity Moho and topography and See Figure 5 for sections locations.

recognized in this area. This conclusion is fully compatible with [31] [40] who argued that these regions uplifted and affected the crust, probably in the early Cenozoic shortly before the beginning of the CVL magmatism.

The geological structures that overlap with the Moho undulations in the Chad basin are usually linked with rift basins of Early Cretaceous age events [39] [41] [42]. They are usually filled with Cretaceous sediments when they are combined 
Table 3. Relationships between surface or subsurface geological structures and the evidenced Moho undulations. See Figure 5 for Moho structures definition.

\begin{tabular}{|c|c|c|c|c|}
\hline Domain & General setting & $\begin{array}{l}\text { Moho } \\
\text { structure }\end{array}$ & $\begin{array}{l}\text { Surface/subsurface } \\
\text { correlation }\end{array}$ & References \\
\hline $\begin{array}{l}\text { Cameroun } \\
\text { volcanic line }\end{array}$ & $\begin{array}{l}\text { Two low ridges } \\
\text { parallel with the } \\
\text { Tertiary uplifts axis }\end{array}$ & $\begin{array}{c}\text { CVLd } \\
\left(\mathrm{M}_{1}, \mathrm{M}_{2}\right)\end{array}$ & $\begin{array}{l}\text { the Adamawa and Month } \\
\text { Cameroon Tertiary uplifts }\end{array}$ & [4] [31] [40] \\
\hline $\begin{array}{l}\text { The Central } \\
\text { African Shear } \\
\text { Zone }\end{array}$ & $\begin{array}{c}\text { single high ridge } \\
\text { slightly parallel } \\
\text { with the } \\
\text { Oubanguides orogeny }\end{array}$ & $\begin{array}{l}\text { CASZd } \\
\left(\mathrm{M}_{4}\right)\end{array}$ & $\begin{array}{l}\text { Cretaceous remnant } \\
\text { east-west dextral shear zone. }\end{array}$ & {$[3][4]$} \\
\hline $\begin{array}{l}\text { The Congo } \\
\text { craton domain }\end{array}$ & $\begin{array}{l}\text { Concentric with the } \\
\text { Congo basin }\end{array}$ & $\begin{array}{l}\mathrm{CCd} \\
\left(\mathrm{M}_{3}\right)\end{array}$ & $\begin{array}{l}\text { Post Precambrian rifting } \\
\text { subsidence and thermal } \\
\text { relaxation. }\end{array}$ & [6] [30] [44] \\
\hline $\begin{array}{c}\text { Chad Basin } \\
\text { domain }\end{array}$ & undefined & $\mathrm{CBd}$ & Early Cretaceous age events & [39] [41] [42] \\
\hline
\end{tabular}

with low topographic. These observations may suggest that the development of the Moho undulations recognized is contemporaneous with the opening of the south and central Atlantic beginning around $130 \mathrm{Ma}$ when wrench fault zones generated strike-slip movements that expanded into extensional sedimentary basins in Niger, Kenya and Sudan.

The axis of the Central African Shear Zone (CASZ) appears to at some extent follow the Moho undulations on this area. There is no clear geological or geophysical evidence if there is a link between Moho undulations and the orogenic events that formed this shear zone. However, this structure is likely to indicate a remaining part of an east-west dextral and shear zone of Cretaceous age. The zone has regenerated several times, and was associated with dextral movements, in connection with the opening of the South Atlantic in the Cretaceous period [4] [43]. We speculate that this feature may have been related at Moho level with a confine upwelling of the mantle, as seismic studies suggest that the crust beneath the Central African Shear Zone shows a remarkable low velocity anomaly [7] [27].

The geological structures that overlap with the near circular shape Moho undulations of the Congo basin (CB) might suggest that the Moho undulations mapped in this area must have been formed almost at the same time as the basin. This basin is an intracratonic basin, with complex formation mechanism. However, [44] suggest that development of the Congo Basin is linked with Precambrian rifting and subsided by post-rift thermal relaxation. From these observations we may speculate that the buildup of the related Moho undulations most be linked with the basin post rift subsidence, possibly in the Mesozoic-Cenozoic times, as [45] argued that the actual morphology of this basin was acquired at that times.

Although we have been using modern gravity data, all the geologic evidences show that the Moho undulations we depicted here might be dating back to the 
Early Cretaceous or to the Tertiary. There is no clear arrangement in the distribution of the real stress directions, and there is no reason to believe that the Moho undulations are still developing in Cameroon. However, recent seismic reflection interpretation indicates the presence of a Late Precambrian rift zone under the sedimentary section in the Congo basin as a consequence, the continuous subsidence of the basin [30]. This subsidence must have an influence on the Moho geometry in this area, even though the significance of this influence is yet to be determined.

\section{Conclusions}

The present work aims at constructing a model of the Moho undulations in Cameroon and adjacent areas. The Moho is an oscillating boundary of a strong density contrast, which is interpreted as the transition between the lower crust and mantle. The density contrast across the boundary and the depth of the boundary are obtained during the modeling of a set of $2.5 \mathrm{D}$ profiles using the constraints of existing seismic sounding profiles

The following preliminary output can be deduced from the present study.

1) The methodology used to estimate undulations of the Moho provides suitable results that are slightly similar with those of the seismic data in most places, and with this technique, it has been possible to estimate the full map of the Moho undulation all over Cameroon and adjacent areas. However, as in this study we focused to better trace in plan view the continuity and the magnitudes of the Moho undulations, the amplitude differences between the gravity and the seismic Moho should not result to wrong interpretations.

2) In many places, the amplitude of the Moho undulations do not seem to be strongly correlated to the surface topography, therefore, the crust may not be in isostatic equilibrium in Cameroon.

3) A Correlation with the surface geology indicates that the Moho undulations in Cameroon can be related to the build-up of the West and Central African rift system dating back to the Early Cretaceous to Palaeogene, where the presence of intraplate tensional stresses reactivated previous shear zones of lithospheric weakness during the break up of Gondwana.

However, our result assumes a constant density contrast throughout the area. The area being formed by association of distinct tectonic units, the presence of lateral variations of density contrast cannot be excluded. A Moho deepening could thus be replaced by a shallower Moho, capped by a low-density lower crust. Analogously, a high density lower crust would appear as a Moho high. At the present level of knowledge it is hard to introduce further details on the density structure of the crust, as sufficient further information is not available. It is therefore vital that additional new knowledge like seismic reflection profiles, stress map and other measurements in the West and Central African rift System should be added to the model to better constrain the proposed conclusions. 


\section{Acknowledgements}

We are very grateful to the authorities of the Bureau Gravimetrique International (BGI) for making available the gravity grids. Alain Pierre Tokam helped with the calculation density constrains.

\section{References}

[1] Shin, Y.H., Shum, C.K., Braitenberg, C., Lee, S.M., Na, S.H., Choi, K.S. and Lim, M. (2015) Moho Topography, Ranges and Folds of Tibet by Analysis of Global Gravity Models and GOCE Data. Scientific Reports, 5, Article No. 11681. https://doi.org/10.1038/srep11681

[2] Paoletti, V., Hansen, P.C., Hansen, M.F. and Fedi, M. (2014) A Computationally Efficient Tool for Assessing the Depth Resolution in Large-Scale Potential-Field Inversion. Geophysics, 79, A33-A38. https://doi.org/10.1190/geo2014-0017.1

[3] Steffen, R., Steffen, H. and Jentzsch, G. (2011) A Three-Dimensional Moho Depth Model for the Tien Shan from EGM2008 Gravity Data. Tectonics, 30, TC5091. https://doi.org/10.1029/2011TC002886

[4] Poudjom Djomani, Y.H., Nnange, J.M., Diament, M., Ebinger, C.J. and Fairhead, J.D. (1995) Effective Elastic Thickness and Crustal Thickness Variations in West-Central Africa Inferred from Gravity Data. Journal of Geophysical Research, 100, 22047-22070. https://doi.org/10.1029/95JB01149

[5] Tokam, A.P.K., Tabod, C.T., Nyblade, A.A., Julià, J., Wiens, D.A. and Pasyanos, M.E. (2010) Structure of the Crust Beneath Cameroon, West Africa, from the Joint Inversion of Rayleigh Wave Group Velocities and Receiver Functions. Geophysical Journal International, 183, 1061-1076. https://doi.org/10.1111/j.1365-246X.2010.04776.x

[6] Reusch, A.M., Nyblade, A.A., Wiens, D.A., Shore, P.J., Ateba, B., Tabod, C.T. and Nnange, J.M. (2010) Upper Mantle Structure beneath Cameroon from Body Wave Tomography and the Origin of the Cameroon Volcanic Line. Geochemistry, Geophysics, Geosystems, 11, Q10W07. https://doi.org/10.1029/2010GC003200

[7] Guidarelli, M. and Aoudia, A. (2016) Ambient Noise Tomography of the Cameroon Volcanic Line and Northern Congo Craton: New Constraints on the Structure of the Lithosphere. Geophysical Journal International, 204, 1756-1765. https://doi.org/10.1093/gji/ggv561

[8] Nédélec, A. and NSIFA, E. (1987) Le complexe du Ntem (Sud-Cameroun): Une série tonalito-trondhémitique archéenne typique. Colloquium on African Geology, Berlin, 18-22 August 1987, Vol. 14, 3-6.

[9] Boukeke, D.B. (1994) Structures crustales d'Afrique Centrale déduites des anomalies gravimétriques et magnétiques: Le domaine précambrien de la République Centrafricaine et du Sud Cameroun. Doctoral Dissertation.

[10] Globig, J., Fernàndez, M., Torne, M., Vergés, J., Robert, A. and Faccenna, C. (2016) New Insights into the Crust and Lithospheric Mantle Structure of Africa from Elevation, Geoid, and Thermal Analysis. Journal of Geophysical Research: Solid Earth, 121, 5389-5424. https://doi.org/10.1002/2016JB012972

[11] Njome, M.S. and de Wit, M.J. (2014) The Cameroon Line: Analysis of an Intraplate Magmatic Province Transecting Both Oceanic and Continental Lithospheres: Constraints, Controversies and Models. Earth-Science Reviews, 139, 168-194. https://doi.org/10.1016/j.earscirev.2014.09.003 
[12] Moreau, C., Regnoult, J.M., Déruelle, B. and Robineau, B. (1987) A New Tectonic Model for the Cameroon Line, Central Africa. Tectonophysics, 141, 317-334. https://doi.org/10.1016/0040-1951(87)90206-X

[13] Ateba, B., Dorbath, C., Dorbath, L., Ntepe, N., Frogneux, M., Aka, F.T., Manguelle, D., et al. (2009) Eruptive and Earthquake Activities Related to the 2000 Eruption of Mount Cameroon Volcano (West Africa). Journal of Volcanology and Geothermal Research, 179, 206-216. https://doi.org/10.1016/j.jvolgeores.2008.11.021

[14] Déruelle, B., Ngounouno, I. and Demaiffe, D. (2007) The "Cameroon Hot Line" (CHL): A Unique Example of Active Alkaline Intraplate Structure in Both Oceanic and Continental Lithospheres. Comptes Rendus Geoscience, 339, 589-600. https://doi.org/10.1016/j.crte.2007.07.007

[15] Ambeh, W.B. and Fairhead, J.D. (1991) Regular, Deep Seismicity beneath Mt Cameroon Volcano: Lack of Evidence for Tidal Triggering. Geophysical Journal International, 106, 287-291. https://doi.org/10.1111/j.1365-246X.1991.tb04618.x

[16] Poudjom Djomani, Y.H., Diament, M. and Wilson, M. (1997) Lithospheric Structure across the Adamawa Plateau (Cameroon) from Gravity Studies. Tectonophysics, 273, 317-327. https://doi.org/10.1016/S0040-1951(96)00280-6

[17] Nono, A., Déruelle, B., Demaiffe, D. and Kambou, R. (1994) Tchabal Nganha Volcano in Adamawa (Cameroon): Petrology of a Continental Alkaline Lava Series. Journal of Volcanology and Geothermal Research, 60, 147-178. https://doi.org/10.1016/0377-0273(94)90066-3

[18] Bonvalot, S., Balmino, G., Briais, A., Kuhn, M., Peyrefitte, A. and Vales, N. (2012) World Gravity Map. Bureau Gravimetrique International (BGI), Map, CGMWBGI-CNES-IRD Ed., Paris.

[19] Balmino, G., Vales, N., Bonvalot, S. and Briais, A. (2012) Spherical Harmonic Modeling to Ultra-High Degree of Bouguer and Isostatic Anomalies. Journal of Geodesy, 86, 499-520. https://doi.org/10.1007/s00190-011-0533-4

[20] Rapolla, A., Cella, F. and Dorre, A.S. (1995) Gravity Study of the Crustal Structures of Somalia along International Lithosphere Program Geotransects. Journal of African Earth Sciences, 20, 263-274. https://doi.org/10.1016/0899-5362(95)00053-V

[21] Lavin, P.M. and Devane, J.F. (1970) Direct Design of Two-Dimensional Digital Wavenumber Filters. Geophysics, 35, 1073-1078. https://doi.org/10.1190/1.1440143

[22] Syberg, F.J.R. (1972) A Fourier Method for the Regional-Residual Problem of Potential Fields. Geophysical Prospecting, 20, 47-75. https://doi.org/10.1111/j.1365-2478.1972.tb00619.x

[23] Zurflueh, E.G. (1967) Applications of Two-Dimensional Linear Wavelength Filtering. Geophysics, 32, 1015-1035. https://doi.org/10.1190/1.1439905

[24] Christensen, N.I. and Mooney, W.D. (1995) Seismic Velocity Structure and Composition of the Continental Crust: A Global View. Journal of Geophysical Research: Solid Earth, 100, 9761-9788. https://doi.org/10.1029/95JB00259

[25] Tabod, C.T., Fairhead, J.D., Stuart, G.W., Ateba, B. and Ntepe, N. (1992) Seismicity of the Cameroon Volcanic Line, 1982-1990. Tectonophysics, 212, 303-320. https://doi.org/10.1016/0040-1951(92)90297-J

[26] Stuart, G.W., Fairhead, J.D., Dorbath, L. and Dorbath, C. (1985) A Seismic Refraction Study of the Crustal Structure Associated with the Adamawa Plateau and Garoua Rift, Cameroon, West Africa. Geophysical Journal International, 81, 1-12. https://doi.org/10.1111/j.1365-246X.1985.tb01346.x

[27] Adams, A.N., Wiens, D.A., Nyblade, A.A., Euler, G.G., Shore, P.J. and Tibi, R. 
(2015) Lithospheric Instability and the Source of the Cameroon Volcanic Line: Evidence from Rayleigh Wave Phase Velocity Tomography. Journal of Geophysical Research: Solid Earth, 120, 1708-1727. https://doi.org/10.1002/2014JB011580

[28] Plomerova, J., Babuška, V., Dorbath, C., Dorbath, L. and Lillie, R.J. (1993) Deep Lithospheric Structure across the Central African Shear Zone in Cameroon. Geophysical Journal International, 115, 381-390. https://doi.org/10.1111/j.1365-246X.1993.tb01193.x

[29] Begg, G.C., Griffin, W.L., Natapov, L.M., O’Reilly, S.Y., Grand, S.P., O’Neill, C.J. and Bowden, P. (2009) The Lithospheric Architecture of Africa: Seismic Tomography, Mantle Petrology, and Tectonic Evolution. Geosphere, 5, 23-50. https://doi.org/10.1130/GES00179.1

[30] Crosby, A.G., Fishwick, S. and White, N. (2010) Structure and Evolution of the Intracratonic Congo Basin. Geochemistry, Geophysics, Geosystems, 11, Q06010. https://doi.org/10.1029/2009GC003014

[31] Meyers, J.B., Rosendahl, B.R., Harrison, C.G. and Ding, Z.D. (1998) Deep-Imaging Seismic and Gravity Results from the Offshore Cameroon Volcanic Line, and Speculation of African Hotlines. Tectonophysics, 284, 31-63. https://doi.org/10.1016/S0040-1951(97)00173-X

[32] Pasyanos, M.E. and Nyblade, A.A. (2007) A Top to Bottom Lithospheric Study of Africa and Arabia. Tectonophysics, 444, 27-44. https://doi.org/10.1016/j.tecto.2007.07.008

[33] Ojo, A.O., Ni, S. and Li, Z. (2017) Crustal Radial Anisotropy beneath Cameroon from Ambient Noise Tomography. Tectonophysics, 696, 37-51. https://doi.org/10.1016/j.tecto.2016.12.018

[34] Dorre, A.S. and Rapollia, A. (1993) Regional Gravity Study of Somalia. In: Abate, E., Sagri, M. and Sassi, F.P., Eds., Geology and Mineral Resources of Somalia and the Surrounding Regions, Relazioni Monografia 113, istituto Agronomico per L'Oltremare, Firenze, 397-416.

[35] Hosney, H. (1994) Scientific Report about Gravity Data Processing and Interpretation of the Arab Republic of Egypt. Unpublished Report, Universita di Napoli, Napoli, $12 \mathrm{p}$.

[36] Eyike, A. and Ebbing, J. (2015) Lithospheric Structure of the West and Central African Rift System from Regional Three-Dimensional Gravity Modelling. South African Journal of Geology, 118, 285-298. https://doi.org/10.2113/gssajg.118.3.285

[37] Martinod, J. and Davy, Ph. (1992) Periodic Instabilities during Compression or Extension of the Lithosphere: I. Deformation Mode from an Analytical Perturbation Method. Journal of Geophysical Research, 97, 1999-2014. https://doi.org/10.1029/91JB02715

[38] Lefort, J.P. and Agarwal, B.N.P. (2002) Topography of the Moho Undulations in France from Gravity Data: Their Age and Origin. Tectonophysics, 350, 193-213. https://doi.org/10.1016/S0040-1951(02)00114-2

[39] Cratchley, C.R., Louis, P. and Ajakaiye, D.E. (1984) Geophysical and Geological Evidence for the Benue-Chad Basin Cretaceous Rift Valley System and Its Tectonic Implications: Journal of African Earth Sciences, 2, 141-150. https://doi.org/10.1016/S0731-7247(84)80008-7

[40] Browne, S.E. and Fairhead, J.D. (1983) Gravity Study of the Central African Rift System: A Model of Continental Disruption 1. The Ngaoundere and Abu Gabra Rifts. Tectonophysics, 94, 187-203. https://doi.org/10.1016/0040-1951(83)90016-1

[41] Burke, K. (1976) The Chad Basin: An Active Intra-Continental Basin. Tectono- 
physics, 36, 197-206. https://doi.org/10.1016/0040-1951(76)90016-0

[42] Genik, G.J. (1992) Regional Framework, Structural and Petroleum Aspects of Rift Basins in Niger, Chad and the Central African Republic (CAR). Tectonophysics, 213, 169-185. https://doi.org/10.1016/0040-1951(92)90257-7

[43] Dorbath, C., Dorbath, L., Fairhead, J.D. and Stuart, G.W. (1986) A Teleseismic Delay Time Study across the Central African Shear Zone in the Adamawa Region of Cameroon, West Africa. Geophysical Journal International, 86, 751-766. https://doi.org/10.1111/j.1365-246X.1986.tb00658.x

[44] Buiter, S.J., Steinberger, B., Medvedev, S. and Tetreault, J.L. (2012) Could the Mantle Have Caused Subsidence of the Congo Basin? Tectonophysics, 514, 62-80. https://doi.org/10.1016/j.tecto.2011.09.024

[45] Kadima, E., Delvaux, D., Sebagenzi, S.N., Tack, L. and Kabeya, S.M. (2011) Structure and Geological History of the Congo Basin: An Integrated Interpretation of Gravity, Magnetic and Reflection Seismic Data. Basin Research, 23, 499-527. https://doi.org/10.1111/j.1365-2117.2011.00500.x 